\title{
HUBUNGAN ANTARA PENGETAHUAN TENTANG INFEKSI SILANG DENGAN PENATALAKSANAAN PENCEGAHAN INFEKSI
}

\author{
Intan Puspita Sari", Dhona Afriza**, Masra Roesnoer ${ }^{* * *}$ \\ "Mahasiswa FKG, Universitas Baiturrahmah, Padang \\ *Bagian Penyakit Mulut, FKG, Universitas Baiturrahmah, Padang \\ ${ }^{* * *}$ Bagian Bedah Mulut, FKG, Universitas Baiturrahmah, Padang
}

\section{KATA KUNCI \\ Infeksi silang, pengetahuan, penatalaksanaan pencegahan infeksi.}

\begin{abstract}
ABSTRAK
Infeksi silang menjadi perhatian utama bagi tenaga medis dan tenaga kesehatan lainnya. Dokter gigi dan tenaga kesehatan gigi beresiko berkontak dengan mikroorganisme patogen pada saat merawat pasien, diantaranya termasuk HIV, Virus hepatitis B (HBV), Virus Hepatitis C (HCV), virus herpes simplex tipe 1 dan 2, Mycobacterium tuberkulosis, dan lain-lain. Kurangnya pengetahuan tentang potensi infeksi yang dibawa saliva dan darah serta mengabaikan perlindungan diri dapat membahayakan petugas kesehatan gigi dan pasien. Penelitian ini bertujuan untuk menganalisis hubungan antara pengetahuan tentang infeksi silang dengan penatalaksanaan pencegahan infeksi pada mahasiswa kepaniteraan klinik FKG Baiturrahmah. Jenis penelitian ini adalah penelitian analitik observasional dengan rancangan cross sectional. Populasi dan sampel adalah mahasiswa kepaniteraan klinik FKG Baiturrahmah. Jumlah sampel adalah 154 orang, sedangkan teknik pengambilan sampel secara acak. Pengumpulan data dilakukan pengamatan dengan mengisi formulir pengamatan dan pengisian kuesioner. Data dianalisis menggunakan uji statistik Chi-Square. Hasil penelitian diperoleh bahwa ada sebanyak $69(86,3 \%)$ mereka yang berpengetahuan tinggi melakukan penatalaksanaan pencegahan infeksi dengan baik, sedangkan yang rendah sebanyak $18(24,3 \%)$ yang melakukan penatalaksanaan pencegahan infeksi dengan tidak baik. Hasil uji statistik didapat nilai $\mathrm{p}=0,141$ maka dapat disimpulkan tidak ada perbedaaan proporsi kejadian kategori pengetahuan dengan penatalaksanaan atau tidak terdapat hubungan yang signifikan antara pengetahuan dengan penatalaksanaan pencegahan infeksi.
\end{abstract}

\section{PENDAHULUAN}

Infeksi merupakan salah satu resiko kerja bagi para petugas kesehatan. Mikroorganisme merupakan agen penyebab infeksi, termasuk di dalamnya bakteri, virus, fungi dan parasit. Berbagai macam mikroorganisme yang diduga dapat menginfeksi tenaga kerja medis di kedokteran gigi, diantaranya termasuk HIV, Virus hepatitis B (HBV), Virus Hepatitis C
(HCV), virus herpes simplex tipe 1 dan 2, Mycobacterium tuberkulosis, Staphylococci, Streptococci, dan lain-lain. Adanya orangorang yang terinfeksi virus hapatitis $\mathrm{B}$ dan $\mathrm{C}$ dan HIV, infeksi silang menjadi perhatian utama bagi dokter gigi dan tenaga kerja kesehatan gigi lainnya.

$$
1,2,3,4
$$

Jalur utama terjadinya penularan penyakit infeksi dalam bidang kedokteran gigi yaitu melalui kulit atau mukosa yang terluka oleh 
benda tajam atau jarum suntik. Umumnya infeksi tersebut disebabkan oleh mikroorganisme patogen yang terdapat pada darah, saliva, dan plak gigi. Banyak sumber penularan infeksi pada praktek dokter gigi antara lain tangan, saliva, sekresi saluran pernafasan, debu/partikel pengeburan gigi, percikan darah, pakaian, dan rambut, demikian pula instrumen gigi serta peralatan lainnya.

Dokter gigi, stafnya dan juga pasien memiliki resiko tinggi berkontak dengan mikroorganisme patogen. Saat melakukan berbagai prosedur di dalam rongga mulut pasien. Mikroorganisme tersebut dapat menginfeksi melalui luka atau abrasi pada kulit tangannya. Lesi atau luka pada kulit ini dapat mempermudah penetrasi bakteri patogen dan virus kedalam tubuh. Sebaliknya, pasien pun dapat pula tertular penyakit yang diderita oleh dokter giginya. Hal itu dapat terjadi apabila tangan petugas yang terluka berada dalam mulut pasien, darah yang patogen atau mikroorganisme lainnya akan pindah secara langsung pada mulut pasien. $5,6,7,8$

Sebagian dari masalah yang ada terletak pada fakta bahwa banyak praktisi dan tenaga pembantunya yang gagal mengenali atau memahami potensi infeksi yang dibawa oleh saliva dan darah selama perawatan. Mengabaikan tindakan dan prosedur perlindungan efektif dapat mengakibatkan orang lain, termasuk keluarga praktisi dan pasien lain menghadapi resiko terkena penyakit yang lebih besar. Resiko ini seringkali terabaikan karena sebagian percikan dari rongga mulut pasien tidak mudah dilihat. ${ }^{3}$

Pengendalian infeksi silang bertujuan mencegah terjadinya infeksi akibat penularan baik dari pasien ke dokter gigi atau staf kesehatan maupun sebaliknya. Dalam hal ini, Centre for Disease Control (CDC) merekomendasikan apa yang disebut sebagai kewaspadaan universal (universal precaution). Kewaspadaan universal adalah bahwa semua darah dan cairan tubuh yang berada di lingkungan kerja harus dianggap sebagai bahan yang dapat menimbulkan infeksi. Bersama dengan American Dental Association (ADA), CDC menyusun tahapan kewaspadaan universal sebagai berikut: 1) perlindungan pribadi, 2) sterilisasi dan desinfeksi bahan/alat serta daerah kerja dan desinfeksi permukaan di ruang praktek yang mungkin terciprati atau tersentuh bahan yang terkontaminasi, dan 3) pembuangan limbah yang benar.

Pengamatan yang dilakukan pada mahasiswa FKG Universitas Baiturrahmah, terdapat beberapa mahasiswa yang mengabaikan perlindungan diri sendiri dan pasien saat bekerja terhadap bahayanya infeksi silang. Berdasarkan pengamatan tersebut, peneliti ingin mengetahui lebih lanjut mengenai hubungan antara pengetahuan tentang infeksi silang dengan penatalaksaan pencegahan infeksi pada mahasiswa kepaniteraan klinik FKG Baiturrahmah. 


\section{METODE PENELITIAN}

Jenis penelitian yang digunakan adalah penelitian analitik observasional dengan rancangan Cross sectional. Populasi adalah mahasiswa kepaniteraan klinik Universitas Baiturrahmah yang aktif kuliah berjumlah 253 orang berdasarkan data bulan april 2012 . Besar sampel ditentukan dengan menggunakan rumus Slovin 10 :

$$
\mathrm{n}=\frac{\mathrm{N}}{1+\mathrm{N} \mathrm{e}^{2}}
$$

Keterangan :

$$
\begin{array}{ll}
\mathrm{n} & =\text { besar sampel } \\
\mathrm{N} & =\text { besar populasi } \\
\mathrm{e} & =\text { nilai kritis }
\end{array}
$$

Pada penelitian ini menggunakan derajat kepercayaan 95\%, dengan nilai kritis yang diinginkan sebesar 5\%. Jadi, subjek penelitian yang digunakan sebanyak 154 orang. Teknik pengambilan sampel dari penelitian ini dengan metode simple random sampling.

\section{Prosedur penelitian}

1. Pengetahuan pada penelitian ini yaitu segala sesuatu yang diketahui tentang infeksi silang, infeksi yang didapat di tempat praktek, dan penatalaksaan pencegahan infeksi. Pengukuran pengetahuan dilakukan dengan mengisi lembaran kuesioner yang telah diuji validitasnya.

2. Prosedur pencegahan infeksi silang mengikuti prosedur yang direkomendasikan dari Center for Disease
Control (CDC) mengenai kewaspadaan menyeluruh, yaitu:

a. Menggunakan sarung tangan selama melakukan perawatan dan menggantinya setiap pergantian pasien.

b. Mencuci tangan sebelum dan sesudah merawat pasien.

c. Menggunakan masker selama melakukan perawatan dan menggantinya apabila terlihat basah.

d. Menggunakan jarum suntik sekali pakai dan menggantinya setiap pergantian pasien.

e. Melakukan sterilisasi dan desinfeksi alat.

f. Telah melakukan vaksinasi hepatitis B.

Hasil pengamatan dicatat pada formulir yang telah dibuat. Pengetahuan responden terhadap infeksi silang diukur dengan mengajukan kuesioner yang terdiri dari 13 pertanyaan. Terdiri dari tiga kelompok pertanyaan yaitu pengetahuan umum infeksi silang, pengetahuan infeksi yang didapat pada kedokteran gigi, dan pengetahuan penatalaksanaan pencegahan infeksi. Pemberian skor untuk masing-masing item pertanyaan adalah untuk jawaban $\mathrm{a}=1$, jawaban $\mathrm{b}=2$, jawaban $\mathrm{c}=3$, jawaban $\mathrm{d}=4$. Berdasarkan nilai yang diperoleh dari jawaban nilai minimum 31 dan nilai maksimum 52 kemudian nilai mean 45,11. Kelompok nilai pengetahuan responden dengan skor kurang dari 45,11 dikategorikan 
pengetahuannya rendah dan nilai pengetahuan responden dengan skor 45,11 atau lebih dikategorikan pengetahuannya tinggi.

Penatalaksanaan pencegahan infeksi yang dilakukan responden diukur dengan melakukan pengamatan secara langsung pada saat responden melakukan perawatan pada pasien. Formulir yang terdiri dari 13 pernyataan sesuai dengan prosedur yang direkomendasikan dari Center for Disease Control (CDC) mengenai kewaspadaan menyeluruh diisi dengan memberi tanda $(\sqrt{ })$. Berdasarkan nilai yang diperoleh dari formulir pengamatan nilai minimum 15 dan nilai maksimum 23 kemudian nilai mean 21,03. Kelompok nilai pengamatan responden dengan skor kurang dari 21,03 dikategorikan tidak baik dan nilai pengamatan responden dengan skor 21,03 atau lebih dikategorikan baik.

Data yang diperoleh diuji statistik yang menggunakan uji chi-square. Dalam menganalisa data menggunakan bantuan komputer SPSS 15.0.

\section{HASIL PENELITIAN}

\section{Hasil Analisis Univariat}

\subsection{Pengetahuan Responden Tentang Infeksi Silang}

Data tentang frekuensi responden berdasarkan tingkat pengetahuan tentang infeksi silang dilihat dalam diagram berikut :

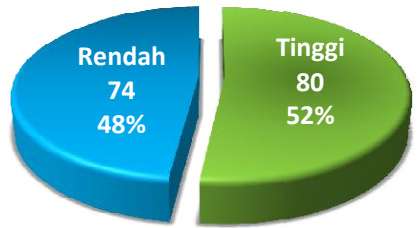

Diagram 1. Frekuensi Responden Berdasarkan Tingkat Pengetahuan Tentang Infeksi Silang

Berdasarkan diagram 1 didapatkan bahwa kurang dari setengah tingkat pengetahuan responden adalah rendah yaitu sebanyak 74 orang $(48 \%)$.

\section{Penatalaksanaan Pencegahan Infeksi Responden}

Data tentang frekuensi responden berdasarkan penatalaksanaan pencegahan infeksi dilihat dalam diagram berikut :

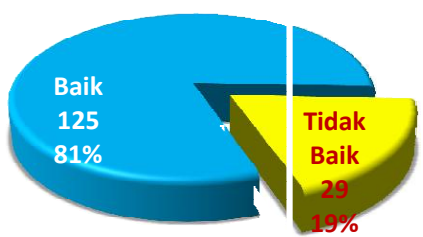

Diagram 2. Frekuensi Responden Berdasarkan Penatalaksanaan Pencegahan Infeksi Responden

Berdasarkan diagram 2 didapatkan bahwa sebagian kecil penatalaksanaan pencegahan infkesi oleh responden dilakukan dengan tidak baik yaitu sebanyak 29 orang (19\%).

2. Hasil Analisis Bivariat

2.1 Hubungan antara Pengetahuan Tentang Infeksi Silang dengan Penatalaksanaan Pencegahan Infeksi pada Mahasiswa Kepaniteraan Klinik FKG Baiturrahmah

Hasil uji Chi-square antara pengetahuan tentang infeksi silang dengan 
penatalaksanaan pencegahan infeksi pada Baiturrahmah sebagai berikut (tabel 1).

mahasiswa kepaniteraan klinik FKG

Tabel 1. Penatalaksanaan Pencegahan Infeksi Berdasarkan Tingkat Pengetahuan Mahasiswa Kepaniteraan Klinik FKG Baiturrahmah

\begin{tabular}{cccccccc}
\hline \multirow{2}{*}{$\begin{array}{c}\text { Pengetah } \\
\text { uan }\end{array}$} & \multicolumn{3}{c}{ Penatalaksanaan Pencegahan } & \multicolumn{2}{c}{ Total } & \multirow{2}{*}{ P Value } \\
\cline { 2 - 5 } & \multicolumn{2}{c}{ Baik } & \multicolumn{3}{c}{ Tidak Baik } & & \\
\cline { 2 - 6 } & $\mathrm{f}$ & $\%$ & $\mathrm{~F}$ & $\%$ & $\mathrm{~F}$ & $\%$ & \\
\hline Tinggi & 69 & 86,3 & 11 & 13,8 & 80 & 100,0 & \\
Rendah & 56 & 75,7 & 18 & 24,3 & 74 & 100,0 & 0,141 \\
\hline Total & 125 & 81,2 & 29 & 18,8 & 154 & 100,0 & \\
\hline
\end{tabular}

Berdasarkan tabel 1 tentang analisis korelasi antara pengetahuan dengan penatalaksanaan pencegahan infeksi pada mahasiswa kepaniteraan klinik FKG Baiturrahmah didapatkan hasil bahwa mereka yang berpengetahuan tinggi melakukan penatalaksanaan pencegahan infeksi dengan baik sebanyak $69(86,3 \%)$, sedangkan yang rendah yang melakukan penatalaksanaan pencegahan infeksi dengan tidak baik sebanyak $18(24,3 \%)$. Hasil uji statistik didapat nilai $\mathrm{p}=0,141$ maka dapat disimpulkan tidak ada perbedaaan proporsi kejadian kategori pengetahuan dengan penatalaksanaan pencegahan infeksi atau tidak terdapat hubungan yang signifikan antara pengetahuan dengan penatalaksanaan pencegahan infeksi.

\section{PEMBAHASAN}

Diagram 1 menunjukkan bahwa kurang dari setengah tingkat pengetahuan responden adalah rendah yaitu sebanyak 74 orang (48\%). Hal ini dibuktikan dari hasil kuesioner yang menunjukkan bahwa 14,9\% responden tidak tahu tentang apa yang dimaksud dengan infeksi silang. Hasil penelitian ini sejalan dengan penelitian yang dilakukan oleh Yusbazioglu et.al (2009) yaitu sebagian besar responden $(74,1 \%)$ tingkat pengetahuannya tinggi tentang infeksi silang. ${ }^{3}$

Diagram 2 menunjukkan bahwa sebagian kecil penatalaksanaan pencegahan infeksi oleh responden tidak dilakukan dengan baik yaitu sebanyak 29 orang (19\%). Hal ini terbukti dari hasil pengamatan dilakukan yang menunjukkan bahwa semua responden (100\%) tidak menggunakan pakaian pelindung hanya di tempat perawatan gigi saja. Penelitian ini sejalan dengan penelitian yang dilakukan oleh Bagg et.al (2001) yaitu sebagian besar responden 75 (70\%) melakukan pencegahan infeksi dengan baik atau sesuai prosedur. ${ }^{12}$

Hasil penelitian bahwa tidak terdapat hubungan yang signifikan antara pengetahuan dengan penatalaksanaan 
pencegahan infeksi. Walaupun tidak terdapat hubungan yang signifikan namun secara proporsi didapatkan bahwa penatalaksanaan dilakukan dengan baik lebih banyak dilakukan oleh responden yang mempunyai tingkat pengetahuan yang tinggi. Hal ini sesuai dengant teori yang disampaikan oleh Sesuai dengan teori Notoatmodjo (2003) yang menyatakan bahwa pengetahuan atau kognitif merupakan domain yang sangat penting untuk terbentuknya tindakan seseorang (over behavior). Pengetahuan berpengaruh pada proses pengambilan keputusan dan aplikasi langsung pada tindakan. Pada suatu keadaan mungkin seseorang sudah memiliki pengetahuan, tapi belum sampai pada tingkat memahami dan aplikasi sehingga tidak timbul dalam prilaku orang tersebut. ${ }^{11}$

Meskipun tidak terdapat hubungan yang signifikan antara tingkat pengetahuan dengan penatalaksanaan pencegahan infeksi oleh responden namun secara proporsi menunjukkan keterkaitan antara tingkat tingkat pengetahuan dengan penatalaksanaan pencegahan infeksi, yaitu semakin tinggi tingkat pengetahuan responden maka penatalaksanaan pencegahan infeksi dilakukan dengan baik, begitu juga sebaliknya jika pengetahuan responden rendah, maka penatalaksanaan pencegahan infeksi dilakukan dengan tidak baik.

\section{KESIMPULAN}

Hasil penelitian menunjukkan bahwa ada sebanyak $69 \quad(86,3 \%) \quad$ mereka yang berpengetahuan tinggi melakukan penatalaksanaan pencegahan infeksi dengan baik, sedangkan yang rendah sebanyak 18 $(24,3 \%)$ yang melakukan penatalaksanaan pencegahan infeksi dengan tidak baik. Namun tidak terdapat hubungan yang signifikan antara pengetahuan tentang infeksi silang dengan penatalaksanaan pencegahan infeksi $(p=0,141)$.

Pengetahuan berpengaruh pada proses pengambilan keputusan dan aplikasi langsung pada tindakan. Pada suatu keadaan mungkin seseorang sudah memiliki pengetahuan, tapi belum sampai pada tingkat memahami dan aplikasi sehingga tidak timbul dalam prilaku orang tersebut.

\section{SARAN}

1. Tim pengajar Universitas Baiturrahmah diharapkan memberikan pelajaran yang lebih mendalam mengenai bahayanya infeksi silang dan penatalaksanaan pencegahan infeksi agar mahasiswa lebih memahami dan mengerti maksud dari segala tindakan pencegahan yang dilakukan.

2. Mahasiswa kepaniteraan klinik lebih berperan aktif untuk mencari informasiinformasi yang akurat mengenai penatalaksanaan pencegahan infeksi yang benar sesuai dengan standar yang direkomendasikan oleh Center for 

Disease
Control
(CDC)
dan menerapkannya saat melakukan perawatan pada pasien .

3. Tim akademik RSGM Baiturrahmah memberikan arahan kepada mahasiswa yang akan melanjutkan pendidikan kuliah profesi di RSGM agar melakukan imunisasi hepatitis B.

4. Untuk mengurangi resiko infeksi silang tim akademik FKG Baiturrahmah menganjurkan pada mahasiswa kepaniteraan klinik untuk menggunakan pakaian khusus lengan panjang yang hanya digunakan diruang perawatan gigi saja.

\section{DAFTAR PUSTAKA}

1. Dwiastuti, S.A.P., Dharmawati, I.A dan Wirata, N. 2008. Hubungan antara Ketersediaan Alat dan Pengetahuan tentang Sterilisasi. Jurnal Skala Husada. 5(2). Hlm 174-175.

2. Wibowo, T., Parisihni, K dan Haryanto, D. 2009. Potensi Dokter Gigi sebagai Pemutus Rantai Infeksi Silang. Jurnal PDGI. 58(2). Hlm 6.

3. Yuzbasioglu, E., Sarac, D., Canbaz, S., Sarac, S dan cengiz, S. 2009. A survey of Cross-Infection Control Procedures: knowledge and attitude of Turkish dentish. J.Appl.Oral Sci. 17(6).

4. Tietjen, L., Bossemeyer, D dan McIntosh, N. 2010. Panduan Pencegahan Infeksi untuk Fasilitas Pelayanan Kesehatan dengan Sumber Daya Terbatas. Penerjemah: Abdul Bari Saifudin, Sudraji Sumapraja, Djajadilaga dan Budi Iman Santoso. Yayasan Bina Pustaka Sarwono Prawirohardjo. Jakarta.

5. Sunoto, R.I. 2008. Tindakan Pencegahan Penularan Penyakit Infeksi Pada Praktek Dokter Gigi (The Practice Of Infection Control In Dentistry). http://abunidathoe.multiply.com/journal/ite $\underline{\mathrm{m} / 32}$ (Diunduh pada tanggal 23 januari 2012 pukul 21:18 WIB)
6. Susanti, D.N.A., Sari, N.N.G dan Wigianto, R. 2002. Tingkat Kebocoran Sarung Tangan lateks sebelum digunakan. Jurnal PDGI. Ed.Khusus. Th ke-52. Hlm 205-206.

7. Miller, C.H dan Palenik, C.J. 2005. Infection Control \& Management of Hazardous Materials for the Dental Team. Ed.Ke-3. Elsevier Mosby. Missouri.

8. Sumawita, N. 2006. Pencegahan Infeksi Silang dalam Perawatan Konservasi gigi. Jurnal Epidemiologi Indonesia. 8(1). Hlm 34-41.

9. Cottone, J.A., Terezhalmy, G.T dan Molinnari, J.A. 2000. Mengendalikan Penyebaran Infeksi pada Praktek dokter gigi. Penerjemah: Lilian Yuwono. Widya Medika. Jakarta.

10. Umar, H. 2008. Desain Penelitian MSDM dan Prilaku karyawan. Ed.1-1. Jakarta. Hlm 69-71.

11. Notoatmojo, S. 2003. Pendidikan dan Prilaku Kesehatan. Rineka Cipta. Jakarta. Hlm 121-124.

12. Bagg, J., Sweeney, C.P., Roy, K.M., Sharp, $\mathrm{T}$ dan Smith, A. 2001. Cross Infection Control Measures and Treatment of Patient at Risk of Creutzfeld Jacob Disease in UK General Dental Practice. British Dental Jurnal. 191(2). Hlm 87-90

13. Afriza, D. 2010. Manisfestasi Penyakit Sistemik di Rongga mulut. Universitas Baiturrhamah. Padang. Hlm 41-49.

14. Bagg, J., Sweeney, C.P., Roy, K.M., Sharp, $\mathrm{T}$ dan Smith, A. 2001. Cross Infection Control Measures and Treatment of Patient at Risk of Creutzfeld Jacob Disease in UK General Dental Practice. British Dental Jurnal. 191(2). Hlm 87-90.

15. Darmadi. 2008. Infeksi Nosokomial Problematika dan Pengendaliannya. Salemba Medika. Jakarta.

16. Eka, C., Riyati, E dan Tjahyaningrum, S.N. 2004. Prevalensi Nursing Mouth Caries pada Anak Usia 15-60 Bulan Berdasarkan Frekuensi Penyikatan gigi di Posyandu Desa Cileunyi Wetan Kecamatan Cileunyi Kabupaten Bandung. http: //resources.inpad.ac.id (Diunduh pada tanggal 27 November 2011)

17. Erfandi. 2009. Pengetahuan Dan FaktorFaktor Yang Mempengaruhi. http://forbetterhealth.wordpress.com (Diunduh pada tanggal 29 mei 2012 pukul 22:20 WIB)

18. Kohli, A dan Puttaiah, R. 2009. Infection Control And Occupational Safety Recommendations For Oral Health 
Professionals. Dental Concil Of India. India. Hlm 6.

19. Oedijani. 2002. Bio-Imunologi Penyakit HIV/AIDS. Jurnal PDGI. Ed.Khusus. Th ke-52. Hlm 461-465.

20. Samaranayake, L. 2006. Essential Microobiology for Dentistry. Ed.ke-3.
Churchill Livingstone Elsevier.

Philadelphia.

21. Sastroasmora, S dan Ismael, S. 2011. Dasardasar Metodologi Penelitian Klinis. Ed.ke-4. CV. Sagung Seto. Jakarta. 